\title{
VIRTUE, HABIT AND NEUROSCIENCE
}

\author{
JOSÉ IGNACIO MURILLO \\ Universidad de Navarra
}

\begin{abstract}
Neuroscience has much to offer to our understanding of human action, including its ethical dimensions. However, while neuroscience has been applied to questions of personal identity, emotion and moral decision-making, its implications for the classical notion of virtue have hardly been considered. This likely has much to do with the way in which the classical notion of virtue, together with closely related concepts of nature and habit, has been forgotten or distorted within the context of modern thought. As a consequence, the standard neuroscientific concept of habit as automatic and routine behavior is fundamentally opposed to teleological activity and thus cannot be reconciled with the classical concept of habit that is essential to virtue. The recovery of the classical notion of virtue in contemporary philosophy invites us to rethink the neuroscientific concept of habit in light of a different view of human behavior for which plasticity is not just indeterminacy but rather openness to freedom and growth.
\end{abstract}

KEY WORDS: Virtue; Habit; Neuroscience; Neuroethics; Freedom; Human Nature; Plasticity.

\section{Virtud, hábito y neurociencia}

RESUMEN: La neurociencia puede ayudar a comprender la acción humana. Pero, aunque ha estudiado algunas dimensiones de la ética como la identidad, las emociones y la toma de decisiones morales, apenas ha tenido en cuenta la noción clásica de virtud. De hecho, la filosofía moral moderna ha olvidado o transformado la noción clásica de virtud y las de naturaleza y hábito, que se encuentran estrechamente vinculadas con ella. Este hecho explica también que la neurociencia disponga de una noción de hábito pobre, que se opone a la actividad teleológicamente orientada y lo comprende como automatismo y rutina. La recuperación de la noción clásica de virtud en la filosofía contemporánea sugiere que puede ser fecundo pensar la neurociencia a la luz de una concepción de la conducta humana que nos permita entender la plasticidad no solo como mera indeterminación sino como apertura a la libertad y al crecimiento.

PALABRAS CLAVE: virtud; hábito; neurociencia; neuroética; libertad; naturaleza humana; plasticidad.

\section{NeUROETHICS AND THE NOTION OF VIRTUE}

Neuroethics emerged as a research field in the early twenty-first century. Along the way, a 2002 conference — sponsored by the DANA Foundation and entitled Neuroethics: Mapping the field - was an important milestone in its development. Within the framework of this conference, neuroethics took shape as an interdisciplinary field driven by the development of another interdisciplinary field we call neuroscience. Neuroethics developed as a special part of bioethics, with the peculiarity that it not only deals with the ethical problems linked to research in a certain area of knowledge and the application of its results, but also directly confronts larger issues in ethics insofar as it inquiries into the neural bases of questions such as the self, action and responsibility ${ }^{1}$.

1 Cfr. Giménez-Amaya, J. M., Sánchez-Migallón, S., De la Neurociencia a la Neuroética. Narrativa científica y reflexión filosófica (Eunsa, Pamplona, 2010), 89 ss. 
Neuroethics' proposal poses a challenge to ethics. If we accept it, ethics must not only address moral action and moral experience as they appear in our conscience; it must also inquire into all available and relevant information concerning our moral actions and valuations, without renouncing the biological and neural bases that are undoubtedly involved in them.

According to many naturalistic philosophers, what we call ethics and moral action can be fully explained by neuroscience. This is not, of course, an obvious thesis since it proposes a naturalisation program that is far from having proven its explanatory capacity. It also presupposes a vision of neuroscience that excludes, in principle, the contribution of non-reductionist philosophical traditions. However, these traditions have recently seen resurgence in their influence; for them, inquiry into the neural bases of human behaviour also provides knowledge and, in addition, gives them the opportunity to test theses reached through other methods.

The project of enriching ethics with new scientific discoveries requires cooperation between those who cultivate both the philosophical and scientific disciplines. It also forces us to question strict demarcations between fields of knowledge that are often held out as a requirement for academic rigor. In this way, ethics ceases to be an exclusive field for philosophers and takes on a role in scientific endeavour, opening up the possibility of recovering the search for unity and coherence of knowledge that modern science has endangered.

Now, although neuroscience has studied various dimensions of ethics, such as identity, emotions and moral decision-making, studies on other notions that the philosophical enquire considers important are lacking. One such notion is that of virtue. This is not surprising if we take into account that modern and contemporary moral philosophy, which has shaped the theoretical agenda in this field, does not particularly understand virtue as an important component of morality. Virtue was, however, central to ancient and medieval ethics. In the twentieth century, scholars from various inspirations began to argue for the resurgence of virtue's centrality in ethics ${ }^{2}$, and this fact leads us to ask what neuroscience can bring to bear on our knowledge of virtue and, conversely, what the notion of virtue can contribute to neuroscience.

Some could argue that virtue has been little studied because what «folk psychology» tends to denote with this word can be sufficiently explained with other notions that have greater scientific-experimental, that is, through neural mechanisms and processes that have nothing to do with philosophers' understanding of it. Thus, for example, neuroscience talks about the reinforcement of neural connections, the codification of motor routines in the basal ganglia, or changes in mechanisms of reward. Some can purport that these approaches fully cover what was once somewhat naively called «virtue».

This divorce between moral philosophy and neuroscience is understandable if we take into account that much philosophical reflection on virtue tends to

2 Cfr. Macintyre, A., After Virtue. A Study in Moral Theory (University of Notre Dame Press, Notre Dame, 2007, $3^{\text {rd }}$ ed.); АввÁ, G., Felicità, vita buona e virtù. Saggio di filosofía morale (LAS, Roma 1995). 
obviate not only the neural but also the anthropological conditions of possibility, understood in a broader sense, of what philosophers mean by virtue. Why are we able to acquire virtues? How do we have to be constituted to make this possible? What does it imply that virtue is achieved through action, or rather, with certain types of actions? Ultimately, the classical notion of virtue held that this is a type of habit or learning, but these two notions - which are present in psychology and neuroscience- are poorly studied by moral philosophy. This omission, together with the ambiguity of the term "habit» ${ }^{3}$, adds to confusion around the notion of virtue and explains why it has all too often been forgotten in the scientific approach ${ }^{4}$.

\section{THE NOTION OF HABIT IN SCIENTIFIC RESEARCH AND MODERN THINKING}

In psychology and in current neuroscience, the content of the classical notion of habit appears under diverse rubrics. Psychology studies it primarily in the context of learning, where the notion of conditioning in its various forms, both classical and operant, takes on special importance. Both presuppose that behaviour changes as a consequence of experience and action. But the semantic root of the term habit is also found in the scientific term "habituation", whose opposite is "sensitisation", which is usually considered a form of nonassociative learning and contains a clear reference to the active adaptation of the organism, in this case sensitivity to environmental influences.

The term habit is also used to designate the result of a process by which certain behaviour becomes habitual, where "habitual» indicates its automatic nature and the promptness with which it is triggered in certain circumstances. Therefore, it is not surprising that the notion of habit frequently evokes negative phenomena such as addictive behaviours, obsessive-compulsive disorders or stereotypes ${ }^{5}$.

Unlike ethics, neuroscience does not focus on behaviour, but on the brain processes that correlate to it. Therein, what is often called habit is reflected in the notion of implicit memory, which, in the words of Daniel L. Schacter, «is revealed when previous experiences facilitate performance on a task that does not require conscious or intentional recollection of those experiences» and «involves changes in behaviour or execution that are the result of past

3 Cfr. Romano, C., "L'équivoque de l'habitude», Revue germanique internationale, 13 (2011), pp. 187-204.

4 However, in the last years, some interesting studies have appeared that look into the notion of virtue from the perspective of neuroscience: CASEBEER, W. D., «Moral cognition and its neural constituents», Nature Reviews. Neuroscience, vol. 4/X (2003) 841-846; Muldins, A. P. J., "Philosophical Prerequisites for a Discussion of the Neurobiology of Virtue», Ethical Perspectives, 4 (2016), pp 681-708.

5 Graybiel, A. M., «Habits, rituals and the evaluative brain», Annu. Rev. Neurosci., 31, pp. 359-387. 
experiences, even when those experiences cannot be consciously remembered ${ }^{6}$. Implicit memory is opposed to explicit memory, which corresponds to that which we can consciously recover. On the other hand, implicit memory is not necessarily linked to the possibility of remembering the experiences that created it, as in the case of some amnesia patients who retain certain abilities without the awareness of having learned them at some point in their lives. In fact, it is worth asking if some of these memories possibly formed by virtue of experiences that were never conscious. The answer is affirmative if we consider that some skills are acquired in early childhood, a stage at which we are not entirely aware, or at least not at the same level of consciousness that appears later.

Among philosophy's contributions to the study of memory, Schacter considers Maine de Biran's (1766-1824) work especially relevant. In his 1987 critical review on implicit memory, Schacter highlights the distinction between the types of memory that de Biran proposes, including mechanical, sensitive and representative. "The first two types», Schacter explains, "are driven by habit and are involved in the largely unconscious or implicit expression of repeated movements (mechanical) and feelings (sensitive); the third type (representative) is involved in conscious recollection of ideas and events» ${ }^{7}$.

Much of what we call habit is made up of learned emotional or mechanical responses, which are defined by not needing to be accompanied by consciousness in order to be effectively put into practice. Thus, thanks to acquired habits, the pianist can unburden his conscience with regard to his hands' movements to deal with the meaning and expressiveness of the music he plays. In addition, thanks to habit, actions that were once difficult, such as getting out of bed at a certain time or drinking beer, become simple and even desirable. They constitute examples of mechanical or sensitive memory, although this distinction does not entirely disentangle these aspects in reality.

It is, however, striking that Schacter affirms that, while maintaining that Plato and Aristotle were broadly concerned with the nature of memory, «both appear to have been concerned exclusively with explicit memory» ${ }^{8}$. Apart from this statement, his mention of classical antecedents regarding implicit memory begins with Descartes and with other modern thinkers.

Yet, a brief reading, for example, of Book II of the Nicomachean Ethics suffices to reveal a theory related to Schacter's definition of implicit memory. In it, we find affirmations such as, «...but the virtues we get by first exercising them, as also happens in the case of the arts as well. For the things we have to learn before we can do them, we learn by doing them, e.g. men become builders by building and lyre players by playing the lyre; so too we become just by doing just acts, temperate by doing temperate acts, brave by doing brave

6 Schacter, D. L., «Implicit memory: history and current status», Journal of Experimental Psychology: Learning, Memory, and Cognition, 13/3 (1987), p. 501.

7 Ibidem, p. 502.

8 Ibidem, p. 502. 
acts» ${ }^{9}$. Techniques and virtues are, for Aristotle, examples of héxis, i.e., habit, which occurs in the soul along with the passions (páthe) and the faculties or capacities (dynámeis) ${ }^{10}$.

But, as mentioned, neuroscience also explicitly uses the term «habit». In a paper that has become a classic for the scientific definition of this concept ${ }^{11}$, Dickinson defines habitual behaviour as opposed to teleological or goal-oriented behaviour. This allows us to define habit in an empirically observable way by reference to reward reduction. In the case of teleological behaviour, animals are sensitive to this, but, to the extent that they acquire habit, reward reduction influences their response less and less.

This vision reflects Maine de Biran's conception, as well as that of other authors interested in habit —among which Ravaisson and William James deserve special mention; they tend to present habit as the mechanical dimension of the spirit or as a relapse of our free and conscious nature into our more instinctive nature. Within this framework there is a positive view of habit that considers its advantages- for example, unburdening consciousness represents the acquisition of certain routines; but there is also a negative one that focuses on its drawbacks linked to loss of previous plasticity and to the possibility that, converted into unconscious factors of behaviour, habit can condition or limit freedom ${ }^{12}$.

It cannot be denied that some habits, such as those associated with technical skills, can also be understood in this context as an extension of freedom, but only in the sense in which other tools are thus considered- they are a clear means for reaching the ends that we freely propose or a kind of instinct that helps us avoid rational calculation and deliberation, and the slowness that such processes imply. Recent studies on decision-making highlight the rapidity of immediate responses and their value for survival, as well as how they are different from rational responses, which are slower, but more reliable and adaptive $^{13}$. In any case, scientists, as much as modern philosophers interested in habit and types of memory habit, tend to frame habit as a principle of automatic, unconscious and rigid conduct, that is to say, opposed to freedom, consciousness and adaptability.

9 ARIstotle, Nichomachean Ethics, II, 1103 a 32-34.

10 ARIstotle, Nichomachean Ethics, II, 1105 b 1-3.

11 Dickinson, A., "Actions and Habits: The Development of Behavioural Autonomy», Philos. Trans. R. Soc. B Biol. Sci., 308 (1985), pp. 67-78.

12 Thus, for example, James argues that habits are manifested in what he calls slips-ofaction, that is, behaviours that continue without conscious supervision once initiated even when they are out of line with the agent's conscious end. For example, this happens when someone is getting changed to go out for the night and ends up in pyjamas and ready for bed instead. Cfr. James, W., Principles of Psychology (New York: Henry Holt, 1890).

13 Kahneman, D., Thinking, Fast and Slow (Farrar, Straus and Giroux, New York, 2011). 
3. The Classical Notion of habit AND the Place of VIRTUE IN NEUROSCIENCE

There is no doubt that Dickinson's notion of habit, and Schacter's idea of implicit memory, are related to the phenomenon that Aristotle described and that the Aristotelian tradition later developed. But these similarities do not do away with the relevant differences. To clarify this issue, we must first distinguish the two different senses in which we commonly refer to habit. One is exemplified by learning certain behaviours or routines, which can be repeated under conscious control, but that unburden consciousness of the details of their execution. The other includes habit understood as a virtue, as well as technical skills, related to know-how. This sense goes beyond the ability to repeat previously learned movements and sees habit as the ability to execute a given complex task regardless of the surrounding circumstances. It is evident that this latter sense of habit cannot be simply identified with a discharge or mechanisation of the spirit, or with the acquisition of a routine. It instead requires another interpretation that directly refers to the relationship between habit and freedom.

To understand this relationship, we must turn to the meaning of the notion of nature in Aristotelian philosophy. Certainly, it is a complex notion with a somewhat tortuous history that has different meanings even within this same tradition. As Spaemann points out, its meaning has often been delimited by opposition to other concepts ${ }^{14}$. Such is the case of the opposition between the natural and the free, or between the natural and the supernatural. What interests us here is that nature refers to the end. In this sense, natural beings, and particularly living beings in the full sense of the word are not indifferent towards those things who do them good and those who harm them. The notion of nature cannot be defined apart from this distinction ${ }^{15}$. Rationality and freedom do not nullify nature; they eliminate the rigidness of the end and broaden its scope. At this point, it makes sense to talk about habits of natural capacities. In effect, «it is when the subject is in potentiality to many things that a habitual disposition is required ${ }^{16}$. But these possibilities are not opposed to nature; rather, they refer to it: "habit implies a disposition in relation to a thing's nature, and to its operation or end, by reason of which disposition a thing is well or ill disposed thereto ${ }^{17}$. Thomas Aquinas recalls that this feature is part of the Aristotelian definition of habit: "Whence also it is stated (Metaph. V) in the definition of habit, that it is a disposition whereby that which is disposed, is well or ill disposed either in regard to itself, that is to its nature, or in regard to something else, that is to the end ${ }^{18}$.

14 Spaemann, R., «Natur», in Philosophische Essays (Reclam, Stuttgart, 1994).

15 Cfr. Murillo, J. I., «Health as a norm and principle of intelligibility», in: García, A. N., Silar, M., Torralba, J. M. (ed.), Natural Law: Historical, Systematic and Juridical Approaches (Cambridge Scholar Publishing, Newcastle, 2008) 361-378.

16 S. Th., I-II, q. 50, a. 1, co.

17 S. Th., I-II, q. 49, a. 4.

18 S. Th., I-II, q. 49, a. 3. 
In this conception, the distinction between positive and negative habits is an essential part of the definition of habit. Is it compatible with current neuroscience? For a biology that claims to be mechanistic, the notion of end only refers to that of a builder who designs according to a plan and not to the type of order found among living beings. But this excluding and limiting assumption is not necessary for biology; indeed, in my opinion, it distances it from an integrating and holistic vision of the phenomenon of life. On the other hand, biology always implicitly alludes to the end and to the good in expressions such as health, adaptation, etc. In this sense, I think that the Aristotelian notion of habit can improve contemporary views of behaviour and expand our understanding by attending to phenomena that are barely perceptible in other paradigms. It is not out of place to distinguish between good and bad habits when considering whether they are desirable or not ${ }^{19}$, but the Aristotelian view allows us to intrinsically distinguish between bad habits, that is, ones that are cognitively lacking, and good habits, that is, ones that are cognitively enriching. The former are merely impoverished and isolated routines, while the latter not only do not reduce the agent's possibilities but, on the contrary, they improve and expand them ${ }^{20}$.

In what follows, I will turn to some of the characteristics of habit and virtue as Thomas Aquinas describes them since Aquinas was one of the great heirs to and promoters of the Aristotelian tradition when it comes to the study of virtue. His work shows the extent of the difference between the classical conception of habit — which is essential for defining and understanding virtue - and the modern one.

Thomas Aquinas defines habit as a type of disposition, but still distinguishes mere dispositions from habits in the strict sense. While disposition is also found in other beings, habits correspond to rational powers. The distinctive feature of habit with respect to disposition is its stability, which does not refer, in my opinion, to the fact that it is impossible to lose them —an impossibility that is clearly not so in the case of moral virtue- but rather habit cannot be totally removed by causes external to the spirit, that is to say, alien to freedom. Nobody can be made unjust, for example, by virtue of a brain injury or, in the words of contemporary scientific concepts, by virtue of an indisposition of bodily humours.

In addition, there is another reason why the notion of habit only attributes habit to rational beings in the Aristotelian tradition -it is not just a way to be better disposed towards the end, but also a kind of growth that enables one to reach higher ends than that which a merely natural endowment allows for. In this sense, Thomas Aquinas speaks of habit as that which allows nature to go beyond its immediate end. "... The proper nature of a power is seen in its relation to its object. Since, therefore, as we have said above (Question 19, article 3 ), the object of the will is the good of reason proportionate to the will,

19 Cfr. Graybiel, A. M., Habits, cit.

20 Bernacer, J., Murillo, J. I., "The Aristotelian conception of habit and its contribution to human neuroscience», Frontiers in Human Neuroscience, 8/883 (2014). 
in respect of this the will does not need a virtue perfecting it. But if man's will is confronted with a good that exceeds its capacity, whether as regards the whole human species, such as Divine good, which transcends the limits of human nature, or as regards the individual, such as the good of one's neighbour, then does the will need virtue. And therefore, such virtues as those which direct man's affections to God or to his neighbour are subjected in the will, as charity, justice, and such like» ${ }^{21}$.

Discussing the notion of an individual end and a common end in this text, as well as several other questions that this text raises, goes beyond the scope of the present contribution ${ }^{22}$. Here, I am interested in highlighting how this notion of habit is different from its conception in modernity, in spite of its kinship. Nature appears in both as a principle that is not fully given or finished. Neuroscience speaks of plasticity in this context. But while plasticity often appears as mere indeterminacy, if we take the classical notion as a reference, we must accept that what is not determined is, from the beginning, oriented towards the end, and that what we call its indeterminacy is the correlate of reason's capacity to go beyond any previously given purpose.

The possibility of habits perfecting nature is based precisely on the imprint that reason, in directing behaviour, leaves on nature and its inclinations. In this sense, virtue is nothing other than the expanded openness of nature to reason, an opening that Thomas Aquinas calls semina virtutum, that is, the seeds of the virtues. In order to avoid the difficulties that the sense of modern rationality can introduce, we can translate this rationalisation of behaviour that habit induces as a cognitive enrichment of said behaviour, understanding cognition in a more «ecological» sense and without restricting it to the simple processing of information.

The relationship that Aquinas establishes between habit and freedom is clearest in his frequent use Averroes' affirmation, "Habit is that whereby we act when we want ${ }^{23}$. We could interpret this statement in line with the abovementioned description of implicit memory. In this case, it only affirms that habit is available to the agent, and it is in this sense that it expands his freedom. But, if we take into account the Aristotelian notion of habit and its further development in Thomas Aquinas, it is also possible to see habit as precisely what allows free disposition with respect to natural endowment. Nature, Thomas Aquinas claims, is oriented to an end (ad unum), and only opens up to opposites (se habet ad opposita) by way of reason. This openness is a condition of freedom, at least in the sense that it opens up the free possibility of acting or not, which only becomes effective by virtue of the imprint that reason leaves

21 Aquinas, S. Th., I-II, q. 56, a. 6 co.

22 Cfr. Murillo, J. I., "Education of desire: moderation or reinforcement?», Bosch, M., (ed.) Desire and Human Flourishing. Perspectives from Positive Psychology, Moral Education and Virtue Ethics, Springer, 2020, pp. 121-134.

23 The expression, "quo quis agitur cum voluerit» or "quo quis utitur cum voluerit», attributed to Averrores, is found in various spots in Thomas Aquinas' work, like, for example in III Sent., d. 14, a. 1, qla. 2; d. 34, q. 3, a. 1 c, sc 1; S. Th., I-II, q. 49, a. 3, sc; q. 51 , a. 1 obi 1 y ad 1; q. 5, a. 5; II-II, q. 137, a. 4, ad 1; In III Ethic., 6; Q. D. De Malo, q. 16, a. 8 etc. 
on the will when it moves a mere natural inclination to the good presented by reason. This thesis is consistent with the possibility of growth in the ability to orient oneself to an end.

Still, we must not forget that the ascent of the notion of virtue is based on Socratic reflection about the good life - that is, the life o a person who pursues the true good, and lives by the conviction that the first and most important impact of human action, in its moral dimension, is on the individual who acts. To affirm, as Socrates does, that it is worse to commit injustice than to suffer it, is to accept the unitary existence through time of a self that can only be intimately affected by her own action.

It is not by chance that Socrates' disciple Aristotle begins his exposition of ethics by talking about happiness ${ }^{24}$. Happiness is nothing other than the good of a self that is seen as an author responsible for her actions over time. Ethics is only directed to those who are capable of being conceived in this way, that is, to those who are capable of proairesis ${ }^{25}$. Action can only revert to the subject if this requirement is met. It is a particular type of reflexivity inherent in voluntary acts, which, to be exercised, always commit the subject as such. This is a requirement of the moral life and is not alien to the nature of habit. In effect, his notion of habit is the consequence of that kind of reflection ${ }^{26}$.

This condition of man is a paradox. Moral action, that is, free action, requires that we be responsible, and for that we have to have a unitary existence throughout time that retains the past and affirms itself as lasting with respect to the future. But, at the same time, free action must recognise, on the one hand, that being a self is also a requirement that must be fulfilled, and, on the other, that it is free action itself that can frustrate this demand.

\section{Challenges AND PERSPECTIVES}

If we accept the reality of the human characteristics herein considered, several challenges are presented to neuroscience: How is this reality translated into biology? How should we understand the human body and its processes so that this notion finds a place in neuroscience? In my opinion, in order to answer this question, it is necessary to frame the study of neuroscience in a context that is broader than the current one. Only by starting from the reality of action as we experience it, as well as by accepting its meta-empirical characteristics,

24 Cfr. Aristotle, Nichomachean Ethics, book I.

25 Cfr. Vigo, A., "Prâxis como modo de ser del hombre. La concepción aristotélica de la acción racional», LeYva MARTínez, G. (ed.), Filosofía de la acción: un análisis histórico-sistemático de la acción y la racionalidad práctica en los clásicos de la filosofía (Síntesis, Madrid, 2008) 53-86. This text has been translated in the book Action, Reason and Truth. Studies in Aristotle's Conception on Practical Rationality, Peeters, Louvain 2016.

26 Murillo, J. I., «Hábito y libertad en Tomás de Aquino», Actes du IX Congrès International de Philosophie Médiéval, Legas, Ottawa 1996, vol. 2, sect. 2, 748-758. 
it is possible to pose the right questions and search in the right direction with the tools and methods that empirical science affords us.

I do not think this deforms neuroscience or any other science that studies human beings and their behaviour. Both psychology and neuroscience, particularly cognitive neuroscience, which study the organic realisation of man's superior functions, cannot avoid having a more or less elaborate notion of the characteristics they study ${ }^{27}$. Rejecting philosophy, understood as the global study of reality, does not result in the disappearance of philosophical conceptions, but rather and more often in accepting the poorest versions and converting them into unjustified prejudices. Perhaps an excessive interest in the first sense of habit, the one that identifies it with a learned mechanism, and the neglect of the second sense has to do with the overly mechanistic and naturalistic (materialist) approaches that condition current neuroscience.

But perhaps both notions, placed in the context of a complete anthropology, have more in common than it may at first seem. As we have seen, the classical notion of habit is not that of a simple acquired capacity, but that of a disposition, and implies an explicit reference to what is or is not good for the living being. If habit can be described as good or bad it is because it implies a relationship between a living being and the ends that give meaning to its nature. But the natural plasticity of higher animals, without which there would be no learning, can only be understood in the framework of life as a certain mode of being that is intrinsically marked by purpose. Thus, for example, the most basic mechanisms of living beings do not appear as a narrowing or increasing rigidity of previously malleable matter, but as an adaptive response of living beings, which to some extent demonstrates that they have some say over their environment. To the extent that we find living beings more capable to learn, it becomes increasingly clear that "narrowing» can only be applied properly to harmful automatisms, which involve what we might call negative learning. All other types of learning, and at various levels, reflect increased environmental exchange. This is so until arriving to habit understood in the strict sense conceived by classical philosophy, which bridges the gap between freedom and nature in such a way that the living being appears as a self in control of its natural faculties. The affinity between implicit memory and habit deserves a second look, therefore, in light of a notion of living beings that does not reduce them to a mere mechanism, but rather properly attributes the classical notion of nature to them.

Universidad de Navarra

Department of Philosophy/Mind-Brain Group (ICS

jimurillo@unav.es

Jose Ignacio Murillo

[Artículo aprobado para revisión en febrero de 2021]

27 Krakauer, J. W., Ghazanfar, A. A., Gómez-Marín, A., Maciver, M. A. and Poeppel, D., «Neuroscience Needs Behavior: Correcting a Reductionist Bias», Neuron 93/3, pp. 480-490. 